\title{
PERILAKU DAN KONFLIK SOSIAL TERHADAP KEPUTUSAN PEMBELIAN PRODUK IKLAN BARU DI TELEVISI
}

\author{
Rustono Farady Marta ${ }^{1}$, Novita Wahyu Setyawati ${ }^{2}$ \\ ${ }^{1}$ Magister Ilmu Komunikasi, Universitas Bunda Mulia, Jakarta Utara, rmarta@bundamulia.ac.id \\ ${ }^{2}$ Program Studi Manajemen, Universitas Bhayangkara Jakarta Raya, Bekasi, \\ novita.wahyu@dsn.ubharajaya.ac.id
}

\begin{abstract}
ABSTRAK
Saat ini produk iklan yang ada di televisi selalu menjadi sorotan bagi para penikmat televisi. Terutama bagi ibu-ibu rumah tangga akan produk rumah tangganya. Apabila ada salah satu produk baru detergen yang baru muncul ditelevisi, beberapa dari mereka terhasut untuk mencoba produk tersebut. Adapula yang tidak terhasut, dikarenakan sudah cocok dengan produk lamanya. Tujuan dalam penelitian ini adalah untuk melihat perilaku dan konflik sosial terhadap keputusan pembelian produk iklan baru di televisi studi kasus Ibu-Ibu Rumah Tangga. Metode penelitian yang digunakan di dalam mengkaji permasalahan ini adalah metode survei dengan analisis deskriptif. Selanjutnya, teknik pengumpulan data dengan observasi, wawancara dan angket yang ditujukan untuk menjaring data-data terkait perilaku, konflik sosial dan keputusan pembelian. Berdasarkan hasil penelitian diperoleh data responden bahwa tingkat kepercayaan terhadap produk yang diiklankan melalui televisi sangat signifikan. Ini terlihat dari nilai sangat percaya sekali $39 \%$, sangat percaya $35 \%$, dan percaya $34 \%$.
\end{abstract}

Kata Kunci: Perilaku, Konflik Sosial dan Keputusan Pembelian

\begin{abstract}
Currently the products in television advertisements are always in the spotlight for television lovers. Especially for housewives for their household products. If there is one new detergent product that has just appeared on television, some of them are incited to try the product. There are also those who are not instigated, because they are compatible with their old products. The purpose of this research is to look at social behavior and conflict towards purchasing decisions of new advertising products on television with housewives as case studies. The research method used in reviewing this problem is a survey method with descriptive analysis. While data collection techniques with observation, interviews and questionnaires are intended to capture data related to behavior, social conflict and purchasing decisions. Based on the results of the study, respondents' data is obtained that the level of trust in the products advertised on television is very significant. This can be seen from the value of very trusting $39 \%$, very confident $35 \%$, and trust $34 \%$.
\end{abstract}

Keywords: Behavior, Social Conflict and Purchase Decision 


\section{National Conference of Creative Industry: \\ Sustainable Tourism Industry for Economic Development}

Universitas Bunda Mulia, Jakarta, 5-6 September 2018

ISSN No: 2622-7436

\section{PENDAHULUAN}

Menghadapi ketatnya persaingan antar ritel,dan memenangkan persaingan, manajemenritel dituntut untuk dapat mendesain, danmengimplementasikan strategi pemasarannyasecara tepat guna mempertahankan danmeningkatkan konsumen. Salah satu upayauntuk mewujudkan tujuan perusahaan tersebutadalah dengan mempelajari perilaku darikonsumen, salah satunya adalah perilaku pembelian secara impulsif. Pembelian impulsive mengacu padaperilaku yang tidak terencana, pembelian secaratiba-tiba yang sering disertai dengan perasaankegembiraan dan kesengangan dan ataudorongan yang kuat untuk membeli.

Perilaku pembelian seseorang dapat dikatakan sebagai sesuatu yang unik, karena preferensidan sikap terhadap objek setiap orang berbeda. Selain itu konsumen berasal dari beberapa segmen,sehingga apa yang diinginkan dan dibutuhkan juga berbeda.

Perilaku konsumen adalah proses yang dilalui oleh seseorang atau organisasi dalam mencari, membeli, menggunakan, mengevaluasi, dan membuang produk atau jasa setelah dikonsumsi untuk memenuhi kebutuhannya. Perilaku konsumen akan diperlihatkan dalam beberapa tahap yaitu tahap sebelum pembelian, pembelian, dan setelah pembelian. Pada tahap sebelum pembelian konsumen akan melakukan pencarian informasi yang terkait produk dan jasa. Pada tahap pembelian, konsumen akan melakukan pembelian produk, dan pada tahap setelah pembelian, konsumen melakukan konsumsi (penggunaan produk), evaluasi kinerja produk, dan akhirnya membuang produk setelah digunakan.Atau kegiatan-kegiatan individu yang secara langsung terlibat dalam mendapatkan dan menggunakan barang dan jasa termasuk di dalamnya proses pengambilan keputusan pada persiapan dan penentuan kegiatan-kegiatan tersebut.

Keputusan pembelian suatu barang atau jasa akan melibatkan berbagai pihak, sesuai dengan peran masing-masing.Peran yang dilakukan tersebut adalah: (1) Initiator, adalah individu yang mempunyai inisiatif pembelian barang tertentu; (2) Influencer, adalah individu yang berpengaruh terhadap keputusan pembelian. Informasi mengenai kriteria yang diberikan akan dipertimbangkan baik secara sengaja atau tidak; (3) Decider, adalah yang memutuskan apakah akan membeli atau tidak, apa yang akan dibeli, bagaimana membelinya; (4) Buyer, adalah individu yang melakukan transaksi pembelian sesungguhnya; (5) User, yaitu individu yang mempergunakan produk atau jasa yang dibeli.Banyak faktor yang mempengaruhi seseorang melakukan pembelian terhadap suatu produk. Manajemen perlu mempelajari faktor-faktor tersebut agar program pemasarannya dapat lebih berhasil. Faktor-faktor tersebut diantaranya adalah faktor ekonomi, psikologis, sosiologis dan antropologis.

Iklan adalah suatu wacana yang memberikan efek kepercayaan bagi pelanggan khususnyauntuk produk-produk yang masih baru ataupun produk-produk yang memerlukan kepercayaan sertakredibilitas tinggi untuk diyakini oleh konsumen akan kualitas dan kinerja produknya. Iklan hanyalahsalah satu contoh untuk mengenalkan produk atau jasa yang ingin di pasarkan kepada pasar sasaran.

Namun iklan sangat berperan penting dalam dunia pemasaran. Tujuan iklan sangat tergantung darisetiap perusahaan, baik untuk menginformasikan, membujuk, atau mengingatkan.

Fenomena yang ada saat ini produk iklan yang ada di iklan televisi selalu menjadi sorotan bagi para penikmat televisi. Terutama bagi ibu-ibu rumah tangga akan produk rumah tangganya. Apabila ada salah satu produk baru detergen yang baru muncul ditelevisi, beberapa dari mereka terhasut untuk mencoba produk tersebut. Adapula yang tidak terhasut, dikarenakan sudah cocok dengan produk lamanya. 


\section{National Conference of Creative Industry: \\ Sustainable Tourism Industry for Economic Development}

Universitas Bunda Mulia, Jakarta, 5-6 September 2018

ISSN No: 2622-7436

Berdasarkan fenomena yang ada dan alasan penelitian, maka peneliti tertarik untuk mengangkat judul Perilaku dan Konflik Sosial Terhadap Keputusan Pembelian Produk Iklan Baru Pada Media TV (Studi Kasus Ibu Rumah Tangga).

\section{TINJAUAN PUSTAKA}

Tinjauan pustaka berisi tentang teori-teori serta hasil penelitian terdahulu dengan menyajikan sub peubah-peubah (variables) yang dimulai dengan peubah gayut (dependent variable), baru kemudian diikuti dengan peubah bebas (independent variable), dan peubah-peubah mediasi atau moderasi (jika ada). Sub berikutnya adalah penyajian hubungan antara peubah terkait yang menjadi landasan logis pengembangan hipotesis penelitian (jika ada) dan gambar rerangka konseptual (conceptual framework). Ditulis dengan menggunakan tipe huruf Times New Roman 12pt, 1 spasi dan rata kiri kanan (justify).

\section{METODE PENELITIAN}

Metode penelitian yang digunakan di dalam mengkaji permasalahan ini adalah metode survei. Metode survei adalah suatu alat untuk mengumpulkan informasi yang menggambarkan suatu perangkat data mengenai jumlah frekuensi dari tingkah laku atau opini dari responden yang telah dipilih. Selain itu, digunakan pula taraf analisis deskriptif, artinya melukiskan variabel demi variabel yang berkaitan. Teknik pengumpulan data dengan observasi, wawancara dan angket yang ditujukan untuk menjaring data-data terkait perilaku, konflik sosial dan keputusan pembelian.

Pembatasan penelitian dilakukan dengan tujuan agar penelitian dapat lebih fokus, terarah, spesifik dan lansung pada permasalahan yang diteliti. Adapun pembatasan penelitian ini dibatasi pada produk baru iklan televisi, segmentasi produk ibu rumah tangga Televisi tersebut adalah Anteve, Indosiar, SCTV, dan RCTI.

\section{HASIL PENELITIAN DAN PEMBAHASAN}

Secara umum tujuan penelitian ini adalah untuk membuktikan secara empiris pengaruh perilaku dan konflik sosial terhadap keputusan pembelian produk iklan baru pada ibu rumah tangga.

Dari keseluruhan persentasi yang paling dominan adalah aktivitas menonton televisi pada ibu rumah tangga mencapai $75 \%$, ini menunjukkan indikasi bahwa kehadiran televisi sangat berpengaruh terutama terhadap perilaku dan konflik social akan adanya iklan produk baru. Preferensi ibu-ibu rumah tangga tentang iklan televisi, memungkinkan terpolarisasi dengan trend-trend iklan baru yang ditayangkan televisi. Disetiap program yang ditayangkan televisi, iklan-iklan bermunculan tanpa melihat kategori iklan dan jam tayang iklan. Persentasi produk iklan terbesar yang diminati ibuibu rumah tangga adalah produk yang dikonsumsi langsung seperti makanan dan minuman mencapai angka $55 \%$, obat-obatan $18 \%$ dan $27 \%$ untuk iklan lainnya. Keberminatan ini dilatarbelakangi oleh persentasi iklan makanan dan minuman di televisi jauh lebih banyak dibandingkan dengan iklan lainnya.

Faktor lain yang dapat menarik perhatian dalam iklan baru adalah model iklan. Model merupakan komponen yang harus dipertimbangkan dalam perencanaan iklan untuk menjawab pertanyaan penting menyangkut "who says". Selain slogan dan model 


\section{National Conference of Creative Industry: \\ Sustainable Tourism Industry for Economic Development}

Universitas Bunda Mulia, Jakarta, 5-6 September 2018

ISSN No: 2622-7436

iklan tersebut, cara lain yang hampir semua pemasar melakukannya adalah repetisi. Repetisi dianggap merupakan teknik yang paling ampuh untuk melekatkan pesan di benak konsumen. Dengan demikian dapat digambarkan bahwa slogan, model, dan repetisi iklan merupakan daya tarik utama iklan untuk menarik perhatian ibu-ibu rumah tangga dalam menyaksikan iklan.

Pada kebanyakan ibu-ibu rumah tangga, perilaku seringkali diawali dan dipengaruhi oleh banyaknya rangsangan (stimuli) yang terus menerus diberikan dari luar dirinya, baik berupa rangsangan pemasaran maupun rangsangan dari lingkungannya sehingga dapat berdampak pada konflik social.Stimulus dalam hal ini iklan, kemudian diproses dalam diri mereka seusai dengan karakteristik dan keinginannya, sebelum akhirnya diambil keputusan pembelian. Karakteristik pribadi merekalah yang dipergunakan untuk mengingat iklan tersebut sangat komplek dan salah satunya adalah motivasi untuk membeli.

Tingkat keberminatan ibu-ibu rumah tangga terhadap produk yang diiklankan sangat tinggi yakni $42 \%$, dan yang dapat dikategorikan tidak berminat hanya $15 \%$. Minat transaksional dan minat referensial menjadi motif yang melatar belakangi mereka untuk berperilaku dalam mengambil keputusan untuk membeli suatu produk baru. Minat referensial menjadi dominan manakala mereka saling bertukar informasi tentang produk yang sudah dibelinya sehingga mempengaruhi ibu rumah tangga lainnya, walaupun hal ini menyebabkan timbulnya konflik social. Dimana konflik social tersebut tidak membuat mereka untuk gampang terpengaruh akan produk iklan baru. Yang menjadi tidak mudah terpengaruhnya adalah persepsi produk iklan baru belum tentu lebih baik dengan produk yang telah mereka gunakan selama ini, harga yang sedikit lebih mahal tetapi kualitas dari produk tersebut baik, dan keterbuktian hasil penggunaan produk tersebut.

Data selanjutnya menjelaskan bahwa $42 \%$ menunjukkan motif perilaku adalah produk yang bagus, kemasannya menarik dan hadiah yang diberikan. 24\% karena pengaruh merk produk yang menjadi jaminan. Dua indikasi ini setidaknya mengambarkan bahwa mereka sebenarnya lebih memilih produk dibandingkan hadiah yang diberikan. Perilaku mereka dalam membeli produk yang diiklankan dilatarbelakangi setidaknya oleh dua faktor. Pertama adalah faktor kemasan produk yang diiklankan, kedua faktor hadiah yang didapat ketika membeli produk tersebut. Faktor kemasan yang menarik, fantastis dan fullcolour memicu untuk membeli. Hadiah juga menjadi pemicu dalam berperilaku untuk mengambil keputusan membeli, dengan anggapan bahwa hadiah yang diperoleh akan jauh lebih menguntungkan dibandingkan dengan uang yang dikeluarkan.

Dari seluruh responden, tingkat kepercayaan terhadap produk yang diiklankan melalui televisi sangat signifikan. Ini terlihat dari nilai sangat percaya sekali $39 \%$, sangat percaya $35 \%$, dan percaya $34 \%$. Kepercayaan terhadap produk iklan lebih dilatarbelakangi oleh cara penyajian iklan, aktor iklan, alur cerita iklan, dan kemasan produk yang ditayangkan. Hal lain seperti kualitas produk, manfaat produk dan efek dari produk tersebut diabaikan.

Pengabaian terhadap ketiga faktor tersebut lebih dikarenakan belum bisa memahami secara optimal tentang kualitas produk-produk yang ditayangkan oleh iklan televisi. Kebutuhan menjadi motivasi utama dalam transaksi jual beli, tetapi dengan adanya tayangan iklan di televisi kebutuhan dapat dielaborasi sedemikian rupa, sehingga segala sesuatu ditempatkan pada posisi kebutuhan primer kemasan produk. $15 \%$ menjawab kurang butuh terhadap produk yang ditayangkan, butuh $21 \%$, sangat 


\section{National Conference of Creative Industry: \\ Sustainable Tourism Industry for Economic Development}

Universitas Bunda Mulia, Jakarta, 5-6 September 2018

ISSN No: 2622-7436

butuh $36 \%$, sangat butuh sekali $10 \%$ dan kurang butuh sekali $18 \%$. Ibu-ibu rumah tangga sebagai responden menjadikan iklan sebagai sarana informasi produk yang akan dibelinya. Ini terlihat dari besarnya kisaran persentasi yang sangat sering membeli produk yang diiklankan, jika dikalkulasikan $75 \%$ sering membeli produk melalui iklan televisi. Sejumlah $36 \%$ responden jarang meminta dukungan keluarganya dalam membeli produk, $21 \%$ sering, $16 \%$ tidak pernah, dan $27 \%$ dikategorikan tidak meminta dukungan keluarganya dalam membeli produk. Ini menunjukkan bahwa dalam mengambil keputusan untuk membeli suatu produk iklan baru sebesar 35\%, responden merasa mempunyai prestise tersendiri atau puas ketika telah memiliki produk yang diiklankan televisi, 30\% sangat bangga, 14\% kurang bangga dan 9\% kurang bangga sekali.

Penyajian iklan, slogan, logo dan sejenisnya merupakan teknik para praktisi iklan untuk meraih simpati dan keberminatan konsumen. Dalam banyak kasus slogan berpengarug terhadap daya ingat konsumen. Di penelitian ini dapat terungkap 54\% responden memilih slogan yang yang menarik dan mudah diingat, $10 \%$ tidak memerlukan slogan, $18 \%$ kurang memerlukan dan $18 \%$ kurang perlu sekali.

\section{KESIMPULAN DAN IMPLIKASI}

Berdasarkan hasil pengujian dan pembahasan penelitian dapat disimpulkan bahwaSlogan iklan televisi, model iklan televisi, repetisi iklan televisi, motivasi, berpengaruh signifikan terhadap perilaku untuk membeli pada produk yang ditayangkan televise. Kelompok ibu-ibu rumah tangga adalah salah satu pasar yang potensial, karena pola mereka yang mudah terbujuk rayuan iklan, suka ikut-ikutan, tidak realistis, dan cenderung mudah dalam menggunakan uangnya, hal inilah yang dimanfaatkan dalam memasuki pasar.Iklan yang disukai adalah iklan yang menarik,bahasa yang mudah dipahami terhadap produk-produk yang diiklankan.Intensitas menonton televisi khususnya tayangan iklan berpengaruh signifikan terhadap perilaku untuk membeli.Dari seluruh responden, tingkat kepercayaan terhadap produk yang diiklankan melalui televisi sangat signifikan. Ini terlihat dari nilai sangat percaya sekali 39\%, sangat percaya $35 \%$, dan percaya $34 \%$. Kepercayaan terhadap produk iklan lebih dilatarbelakangi oleh cara penyajian iklan, aktor iklan, alur cerita iklan, dan kemasan produk yang ditayangkan.

Berikut implikasi dalam penelitian ini adalah bahwa periklanan merupakan salah satu tahap dalam pemasaran. Tanpa periklanan, berbagai produk tidak akan dapat mengalir ke para distributor atau penjual apalagi ke konsumen. Iklan akan bisa bermanfaat bagi perusahaan dalam pelaksanaan fungsi-fungsi pemasaran, maka suatu periklanam harus fleksibel, stabil, berkesinambungan dan sederhana serta mudah untuk dipahami. Hal ini memerlukan analisis, peramalan dan pengembangan usaha periklanan dengan mempertimbangkan segala sesuatu pembuatan iklan sebagai proses yang berkesinambungan. Agar iklan tepat dengan sasaran yang di kehendaki maka pengiklan harus bisa menciptakan iklan yang efektif dengan memperhatikan perilaku dan segmen atau konsumen yang hendak dituju.

\section{DAFTAR PUSTAKA}

Amirullah. (2002) Perilaku Konsumen Edisi Pertama. Yogyakarta: Graha Ilmu 


\section{National Conference of Creative Industry: \\ Sustainable Tourism Industry for Economic Development}

Universitas Bunda Mulia, Jakarta, 5-6 September 2018

ISSN No: 2622-7436

Anoroga, P. (2000). Manajemen Bisnis. Jakarta: PT Rineka Cipta

Kotler, Amstrong. (2006). Prinsip-Prinsip Pemasaran Jilid 1. Jakarta: Penerbit Erlangga

Kotler, Philip. (2002). Manajemen Pemasaran Edisi Millenium 2. Jakarta: Prehalindo

Purnama, Lingga. (2001). Strategic Marketing Plan. Jakarta: Gramedia Pustaka Utama

Ridwan Effendi, (2006). Pendidikan Lingkungan Sosial Budaya dan Teknologi. Bandung: UPI PRESS.

Schiffman, Leon G., Kanuk, Leslie Lazar. (2007). Perilaku Konsumen. Jakarta: Indeks

Shimp, Terence A. (2000). Periklanan Promosi Jilid I, Jakarta: Erlangga.

Shimp, Terence A. (2000). Promosi dan Periklanan, Aspek Tambahan Komunikasi Pemasaran Terpadu. Jakarta: Erlangga.

Triyaningsih. (2011). Dampak Online Marketing Melalui Facebook Terhadap Perilaku Konsumtif Masyarakat. Jurnal Ekonomi dan Kewirausahaan

\section{BIODATA}

\section{Biografi singkat Penulis Pertama}

Rustono Farady Marta atau yang akrab dipanggil "Frad" ini memperoleh gelar Sarjana pada Program Studi Ilmu Komunikasi di Universitas 17 Agustus 1945 Surabaya, kemudian melanjutkan studi jenjang S2 pada Program Magister Media \& Komunikasi (MedKom) di Universitas Airlangga Surabaya. Pencapaian puncak studi dituntaskan dari Program Doktor Ilmu Komunikasi Universitas Indonesia pada tahun 2017, sembari meluncurkan buku perdana yang ditulis bersama Ibu Supina, S.ST.Par, M.Par., MM. in ITM. dengan judul "GEGAR BUDAYA NUSANTARA: Implementasi Komunikasi Pariwisata Lintas Kultural”. Kini aktifitas sehari-hari Frad mengajar di Universitas Bunda Mulia Jakarta pada tiga program studi, antara lain: Sarjana Ilmu Komunikasi, Bachelor Degree of Hospitality and Tourism, dan Magister Ilmu Komunikasi serta dipercaya mengampu asistensi Prof. Dr. phil. Hana Rochani Guntasari Panggabean, Psi. pada Program Pascasarjana Magister dan Doktor Psikologi Universitas Katolik Indonesia Atma Jaya Jakarta. Di sisi lain, prestasi di bidang riset yang pernah diukir adalah meraih gelar Terbaik III pada Indonesia Media Research Awards and Summit (IMRAS) selama dua tahun berturut-turut untuk kategori social media (2014) dan kategori online media (2015). Pada tahun berikutnya berhasil memperoleh Beasiswa Menulis Ilmiah Populer 2016 oleh Tempo Institute dan masuk dalam jajaran 10 terbaik nasional untuk Kompetisi Proposal Riset Anti-Korupsi Jurnal Integritas 2018 yang diadakan oleh Komisi Pemberantasan Korupsi.

\section{Biografi singkat Penulis Kedua}

Novita Wahyu Setyawati atau yang akrab dipanggil "Ayu" pada tahun 2002 menuntaskan studi Ilmu Manajemen dengan gelar Sarjana Ekonomi dari Universitas 
Katolik Soegijapranata Semarang, kemudian melanjutkan jenjang Magister pada bidang ilmu yang sama untuk konsentrasi Manajemen Sumber Daya Manusia pada Universitas Krisnadwipayana Jakarta dan dinyatakan lulus pada tahun 2007. Kini pengajar program studi Ilmu Manajemen Universitas Bhayangkara Jakarta Raya ini sedang menempuh studi Program Doktoral ilmu Manajemen Bisnis pada Universitas Padjajaran Bandung. 